\title{
European molecular biology laboratory in search of a director
}

London

THE withdrawal of the only candidate for one of Europe's top scientific posts has created a considerable problem for the governing body of the European Molecular Biology Laboratory (EMBL) in Heidelberg. The most likely outcome of a meeting of EMBL's council on 6 February is that the present director, Lennart Philipson, will be asked to stay on beyond April 1990 , when he was to have been replaced.

The hunt for a successor to Philipson, who has been director since 1982, has been under way for two years. A search committee chaired by the council's chairman, Professor Jan Drenth, scoured Europe for suitable candidates and identified a handful. But only one of them, Professor Tom Blundell of the Crystallography Department, Birkbeck College, London was interested. He withdrew his candidature two weeks ago after some months of negotiation.

At a council meeting last December, it became clear that a small number of the 14 countries that provide EMBL's funds were opposed to Blundell's appointment, and a decision was postponed until next week's special meeting There has been little or no weakening of the opposition and it seems unlikely that the ten votes

\section{BMA scorns loans}

\section{London}

THE British Medical Association (BMA) this week criticized the government's plans to introduce a loans system for students to supplement the current grants system, saying that students would be deterred from entering the medical profession, especially those from poorer families. The profession is disturbed at the prospect that its future stock will be drawn from those who can afford to pay for a medical education rather than those best suited by their ability to benefit from it, says the association, in a letter to the Department of Education and Science.

Surveys reveal considerable disillusionment among young doctors about careers in medicine, says the BMA. Of those qualifying in 1981,46 per cent expressed regret at having entered medicine, compared to 28 per cent in 1976. If young doctors are also faced with large outstanding loans from their undergraduate days, this disillusionment will only get worse. The association estimates that by 2006 a junior doctor could have a total loan to repay of up to 35 per cent of his or her first year's income.

The BMA urges the government to reconsider its plans for a loans scheme and instead to restore the recent loss in real value of the grant. Christine McGourty necessary for the appointment would have been cast at the meeting.

One reason given for opposing the appointment, particularly by the French delegation, was that EMBL should not have a structural biologist as its director. But there was also opposition, much of it from within EMBL, to Blundell's condition that he should be allowed to continue his personal research, even though his proposal was for a modest group of 10 people.

Blundell says he had been greatly looking forward to the challenge of the job, and particularly the task of sorting out the central facilities of EMBL, including its out-stations and the biocomputing laboratory, whose work falls within his own expertise. Instead, he now hopes for rapid progress in his negotiations with the Imperial Cancer Research Fund for a substantial programme of collaborative research.

EMBL's council is faced with the choice of restarting its search for a successor to Philipson or extending his stay. Drenth feels that it would now be in the best interests of the laboratory if Philipson would stay on. And Philipson is believed to be willing to stay if certain conditions are met.

Peter Newmark

\section{Arianespace order}

Paris \& Tokyo

THE night of 27 January was a busy one on launch pads around the world. At 01.21 GMT, Arianespace, the consortium operating European space launches, put an Intelsat $\mathrm{V}$ communications satellite into geostationary orbit. Just a few hours earlier, on the other side of the globe, the Japanese National Space Development Agency successfully launched the TR-1(2) prototype for its $\mathrm{H}$-II rocket.

The European launch from Kourou in French Guiana confirmed Arianespace's lead in the commercial satellite launch market. With an order book for 36 launches, nine of them scheduled for this year, Arianespace hopes to repeat last year's turnover of $\$ 520$ million.

In February, Arianespace will sign an order for 50 Ariane-4 launchers, worth more than $\$ 4,500$ million, and intended to be the company's workhorses until 1999. Japan hopes one day to take a slice of that market. But it will be at least 1992 before the $\mathrm{H}$-II rocket is complete, and commercial launches are not expected to begin until the late 1990s. By then, H-II's 4-tonne payload may look small compared with that of planned new Ariane launchers.

Peter Coles \& Alun Anderson

\section{New chairman}

\section{Munich}

THE West German Wissenschaftsrat (science council) chose Dieter Simon as its new chairman at a meeting in West Berlin on 27 January. Simon, a law scholar and director of the Max Planck Institute for European legal history in Frankfurt, replaces physician Kurt Kochsiek of Würzburg.

Simon led a strike of the scientific review commission of the Wissenschaftsrat in December of last year (see Nature 336, 506; 8 December 1988) to protest at the demotion of the council's general-secretary to the lowly status of a public servant. Pressure from the political heads of the Länder in late December pesuaded the federal government to restore the generalsecretary position, currently unoccupied, to its original higher status.

In his final statement, Kochsiek pleaded with the Länder to increase their education budgets by twice as much as they had planned in order to alleviate overcrowding and a decline of quality at West German universities.

S. D.

\section{New NSF positions}

\section{Washington}

RiCHARD Nicholson, at present assistant director for mathematical and physical sciences at the National Science Foundation, was last week named as the new executive officer of the American Association for the Advancement of Science. He replaces Alvin Trivelpiece who left the association at the end of last year to become director of the Oak Ridge National Laboratory. Nicholson is expected to join the association by mid-April.

The foundation also announced last week that Mary Clutter would take over as assistant director for biological, behavioural and social sciences. She replaces David Kingsbury, who resigned last October amid allegations of conflict of interest over his dealings with a biotechnology company.

\section{Accelerator all set}

\section{Washington}

BACKERS of the Superconducting Super Collider, the proposed $\$ 4,400$-million proton accelerator, now have everything they need except congressional approval for construction funds. Two weeks ago, Waxahachie, Texas, was confirmed by outgoing Secretary of Energy John Herrington as the site of the Superconducting Super Collider after a review of the full environmental impact statement, and last week the Department of Energy signed a nine-year contract with the Universities Research Association, a consortium of 66 universities, to manage and operate the facility. The association runs the Fermi National Accelerator Laboratory near Chicago, and was the only bidder. 